\title{
Control of Magnaporthe oryzae and Rice Growth Promotion by Bacillus subtilis JN005
}

\author{
Huajun Zhu' ${ }^{1,2,3} \cdot$ Hu Zhou ${ }^{1,2,3} \cdot$ Zuohua Ren ${ }^{1,2} \cdot$ Erming Liu $^{1,2,3}$
}

Received: 22 December 2020 / Accepted: 14 July 2021 / Published online: 23 July 2021

(c) The Author(s) 2021

\begin{abstract}
It is quite important to develop the microorganism resources with biocontrol capacity for rice blast. This study evaluated Bacillus subtilis JN005 for growth promotion and biocontrol efficacy against Magnaporthe oryzae. Results showed that rice seeds treated with $1 \times 10^{7} \mathrm{cfu} / \mathrm{mL}$ suspension of B. subtilis JN005 had 16\% germination energy, $14 \%$ germination rate, $15 \%$ germination index, and 270\% vigor index compared to those treated with sterile water (control). In pot experiments, the JN005 strain-treated rice plants exhibited notable increase in plant height, root length, stem circumference, and fresh weight, as well as higher concentration of chlorophyll a, chlorophyll b, and total chlorophyll in rice leaves. Rice leaves inoculated with the JN005 strain resulted in increased activities of defense-related enzymes, including peroxidase (POD), phenylalanine ammonialyase (PAL), superoxide dismutase (SOD), and catalase (CAT) compared to the water and the $M$. oryzae-inoculated treatments. In vitro inoculated rice leaves with $1 \times 10^{7} \mathrm{cfu} / \mathrm{mL}$ bacterial suspension compared to sterile water or control treatment exhibited lower disease incidence in the curative and preventive groups by $79 \%$ and $76 \%$, respectively. Field experiment showed that after spraying with $1 \times 10^{7} \mathrm{cfu} / \mathrm{mL}$ bacterial suspension, efficacy rates on controlling rice blast on plants were $(56.82 \pm 1.12) \%$ and $(58.39 \pm 3.05) \%$ at seedling and maturity stages, respectively, and that rice production yield was $(524.40 \pm 17.88) \mathrm{g} / \mathrm{m}^{2}$. Therefore, B. subtilis JN005 could be a promising biological control agent for rice blast, thereby warranting further investigation of its efficacy.
\end{abstract}

Keywords Bacillus subtilis $\cdot$ Rice $\cdot$ Magnaporthe oryzae $\cdot$ Biological control

\section{Introduction}

Rice blast caused by the Magnaporthe oryzae is one of the most destructive plant diseases, effecting $10 \%$ to $30 \%$ annual global rice output loss (Asibi et al. 2019) that may result in severe economic and humanitarian issues (Miah et al. 2017). Although agrochemicals enable quick and effective control of plant diseases, their excessive use increases the

Handling Editor: Mikihisa Umehara.

Erming Liu

ermingliu@163.com

1 College of Plant Protection, Hunan Agricultural University, Changsha 410128, China

2 Hunan Provincial Key Laboratory for Biology and Control of Plant Diseases and Insect Pests, Changsha 410128, China

3 Southern Regional Collaborative Innovation Center for Grain and Oil Crops in China, Changsha 410128, China potential of resistance buildup in plant pathogens (Wang and Cernava 2020; Majeed 2018). In recent years, some promising and eco-friendly alternatives to chemical control have been developed to curtail plant diseases (Barratt et al. 2018; Emoghene and Futughe 2016). The use of biological control agents has become a trend owing to global development orientations on use of non-chemical alternatives with less negative impact to the environment.

Recent studies have identified bacterial groups as biocontrol agents against plant pathogens that mainly include Pseudomonas spp. and Bacillus spp. (Chen et al. 2020; Sun et al. 2017). Bacillus spp. are gram-positive, rod-shaped, endospore-forming bacteria that have potential to produce diverse bioactive compounds and ability to produce endospores, therefore make them preferable candidates for commercial exploitation as bacterial biocontrol agents (Sowanpreecha et al. 2018; Jangir et al. 2018). To date, 26 microbiological preparations to control rice blast in China have been newly registered (http:// 
www.icama.org.cn/hysj/index.jhtml) that are composed of 22 B. subtilis, 3 B. cereus, and 1 B. amyloliquefaciens strains and are available in 21 wettable powder, 2 suspension concentrate, 2 oil dispersion, and 1 water dispersible granule forms.

Previous studies have shown that $B$. subtilis can promote plant growth and increase crop yield by solubilizing soil phosphorus, thus enhancing nitrogen fixation and producing indole acetic acid and siderophore (Hashem et al. 2019; Lastochkina et al. 2017; Ahmad et al. 2017). In addition, $B$. subtilis has strong antagonistic activities to many plant pathogens, such as Rhizoctonia solani (Tan et al. 2019), Fusarium oxysporum f. sp. niveum (Zhu et al. 2020), and Colletotrichum fructicola (Xu et al. 2020).

Hence, this study aimed to assess the potential of $B$. subtilis JN005 (GenBank: KU302780) for rice blast control and rice growth improvement. This study used $B$. subtilis JN005 to find out if it can effectively inhibit $M$. oryzae growth. The strain was isolated from a healthy rice plant among diseased rice hills of the susceptible cultivar Xiangzaoxian 24, a single-season cropping rice, in the mountainous areas of Taojiang, Hunan, China.

\section{Materials and Methods}

\section{Microorganisms, Media, Plant Materials, and Fungicides}

B. subtilis JN005 and M. oryzae are stored in the Laboratory of Plant Pathogenic Microorganisms and Rice Diseases, Hunan Agricultural University, Changsha, China. Unless otherwise specified, B. subtilis JN005 was grown on Nutrient Agar (NA) (Zhang et al. 2019). The phytopathogenic fungus M. oryzae was cultured and maintained on Potato Dextrose Agar (PDA) (He et al. 2019). The test rice variety was "Xiangwanxian No 12" from Hunan Hope Seed Industry Technology Co., Ltd., China. The fungicides used were B. subtilis WP from Deqiang Biological Co., Ltd., China, $40 \%$ isoprothiolane EC from Jiangsu Longdeng Chemical

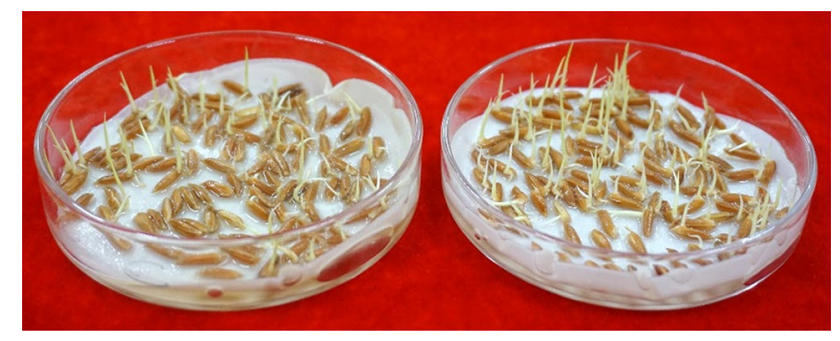

Fig. 1 Effect of Bacillus subtilis JN005 suspension of $1 \times 10^{7} \mathrm{cfu} / \mathrm{mL}$ treatment (right) on rice seed germination in comparison to the control or sterile water treatment (left)

Co., Ltd., China, and 75\% tricyclazole WP from Shanghai Hualian Biopharmaceutical Co., Ltd., China.

\section{Effect of B. subtilis JN005 on Rice Seed Germination}

Rice seeds were soaked in a beaker containing water. Floating seeds were taken out and discarded, while the seeds that sunk were used in research. After removing the water, the seeds were sterilized by immersing in $70 \%$ alcohol for $30 \mathrm{~s}$, then into $1 \%$ sodium hypochlorite for $1 \mathrm{~min}$, and then rinsed off twice with sterile water (Anhar et al. 2019). Afterward, seeds were soaked in sterile water for $24 \mathrm{~h}$, and then 100 seeds were evenly dispersed on petri dishes $(d=9 \mathrm{~cm})$ with two sheets of filter papers moistened with $10 \mathrm{~mL}$ of $B$. subtilis JN005 suspension at various concentrations: $1 \times 10^{8} \mathrm{cfu} /$ $\mathrm{mL}, 1 \times 10^{7} \mathrm{cfu} / \mathrm{mL}$, and $1 \times 10^{6} \mathrm{cfu} / \mathrm{mL}$. Each petri dish was covered with a double wet gauze and then incubated for seven days at $28{ }^{\circ} \mathrm{C}$ in a dark culturing box. Controls were prepared by moistening the filter papers with $10 \mathrm{~mL}$ sterile water. Each treatment had three replicates and each petri dish was weighed every 12-h period, and the evaporated solution of each treatment was replenished to keep the solution concentration consistent during the treatment. Buds were cut, dried, and weighed on the seventh day. The germination energy (GE) was calculated on the fifth day based on the GB/T3543.4-1995 Rules for Agricultural Seed Testing-Germination Test in China. The germination rate (GR), germination index (GI), and vigor index (VI) were calculated on the seventh day:

GE $(\%)=($ number of germinated seeds on the 5 th day $) /($ total number of seeds $) \times 100$

GR $(\%)=($ number of germinated seeds on the 7 th day) $/$ (total number of seeds $) \times 100$

GI $=\sum[$ (days of germination) $/($ corresponding number of germinated seeds $)]$ 
$\mathrm{VI}=\mathrm{GI} \times($ dry weight of buds $)$

\section{Effect of B. subtilis JN005 on Rice Seedlings}

Surface sterilized rice seeds were sown into plastic pots containing field soil at $28{ }^{\circ} \mathrm{C}$ and 12-h light per day. Each pot $(20 \mathrm{~cm} \times 15 \mathrm{~cm} \times 10 \mathrm{~cm})$ was irrigated every seven days with $50 \mathrm{~mL}$ of $B$. subtilis JN005 suspension at various concentrations $\left(1 \times 10^{8} \mathrm{cfu} / \mathrm{mL}, 1 \times 10^{7} \mathrm{cfu} / \mathrm{mL}\right.$, and $1 \times 10^{6} \mathrm{cfu} /$ $\mathrm{mL}$ ) and $50 \mathrm{~mL}$ water for the control setup. Three pots were used for each treatment. Growth parameters of 35-day-old seedlings were measured, including plant height, root length, stem circumference, and fresh weight. Chlorophyll estimation was carried out following the method of Bisht et al. (2020). In brief, $0.10 \mathrm{~g}$ of fresh rice leaf tissue was harvested from each treatment, and was homogenized in $80 \%$ acetone, and centrifuged for $5 \mathrm{~min}$. Then, the supernatant was obtained, and absorbance was measured through the $\mathrm{UV}-\mathrm{Vis}$ spectrophotometer at $645 \mathrm{~nm}$ and $663 \mathrm{~nm}$.

\section{Effect of B. subtilis JN005 on Defense Enzymes Activity}

Rice plants grown in plastic pots $(20 \mathrm{~cm} \times 15 \mathrm{~cm} \times 10 \mathrm{~cm})$ containing field soil at $28^{\circ} \mathrm{C}$ and 12 -h light per day were sprayed with various liquid treatments at 25 days. The experiment was designed with three replications and four treatments, viz, water $\left(\mathrm{T} 1=\right.$ negative control), $2 \times 10^{5}$ conidia/ $/ \mathrm{mL} M$. oryzae suspension $(\mathrm{T} 2=$ positive control $), 1 \times 10^{7} \mathrm{cfu} / \mathrm{mL}$ B. subtilis JN005 suspension (T3), and $1 \times 10^{7} \mathrm{cfu} / \mathrm{mL}$ B. subtilis JN005 the bacterial suspension $24 \mathrm{~h}$ after being inoculated with the spore suspension. Other treatments used were sterile water (control), 40\% isoprothiolane EC, and 75\% tricyclazole WP in place of the JN005 strain suspension. All petri dishes were placed at conditions of $85 \%-100 \%$ relative humidity and temperature of $28{ }^{\circ} \mathrm{C}$, with a 12 -h photoperiod for seven days. Disease incidence was measured from 15 leaves for each treatment.

Disease incidence (\%)

$=($ number of disease spots/number of spots investigated $) \times 100$

\section{Effect of B. subtilis JN005 on Rice Blast in the Field}

A two-year field experiment was carried out at experimental site of Taojiang, Hunan province, China (N28 42'55.56", E1 $\left.12^{\circ} 15^{\prime} 74.24^{\prime \prime}\right)$, where rice blast occurred frequently to evaluate the efficacy of $B$. subtilis JN005 on rice blast. The experimental site had sandy loam soil with $5.6 \mathrm{pH}$ and $1.09 \%$ organic matter.

Before being sown in $30 \mathrm{~m}^{2}$ field plots, the rice seeds were dressed separately in B. subtilis JN005 suspension $\left(1 \times 10^{7} \mathrm{cfu} /\right.$ $\mathrm{mL})$, B. subtilis WP fungicide, and water. All treatments were replicated three times in a randomized complete block design (RCBD). In the same treatment of field plots, rice plants at tillering and heading stages received treatments of $B$. subtilis JN005 suspension $\left(1 \times 10^{7} \mathrm{cfu} / \mathrm{mL}\right)$, B. subtilis WP, and water. The disease severity survey was conducted at seedling and maturity stages, and rice yield was investigated at maturity stage. Leaf blast and panicle blast were scored following the 0-9 scale of the International Standard Evaluation System of Rice (SES) by the International Rice Research Institute (IRRI).

Disease index

$=\sum[$ (number of infected plants in each category $\times$ numberical values of each catergory)/(totol number of plants $\times$ highest numberical values $\left.)\right] \times 100$

suspension $+2 \times 10^{5}$ conidia/mL M. oryzae spore suspension (T4). Rice leaf samples were collected at $1,3,5$, and 7 days after treatment. The activities of catalase (CAT), phenylalanine ammonialyase (PAL), peroxidase (POD), and superoxide dismutase (SOD) were examined using a relative kit (Nanjing Jiancheng Bioengineering Institute, China).

\section{Effect of B. subtilis JN005 on Rice Blast Development on Detached Rice Leaves}

Detached healthy rice leaves at the five-leaf stage were poked slightly with an inoculating needle and then placed into petri dishes with $0.1 \%$ 6-benzylaminopurine solution. For the preventive group, leaf surfaces were sprayed with $B$. subtilis JN005 suspension of $1 \times 10^{7} \mathrm{cfu} / \mathrm{mL}$ first and were inoculated with $M$. oryzae spore suspension of $2 \times 10^{5}$ conidia $/ \mathrm{mL}$ after $24 \mathrm{~h}$. For the curative group, leaf surfaces were sprayed with

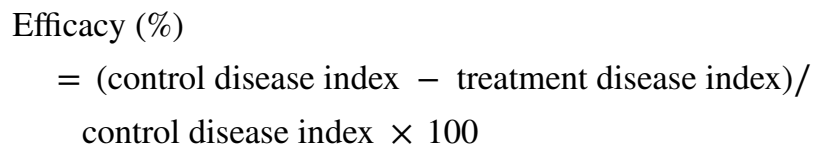

\section{Statistical Analyses}

All analyses were carried out using the Dunnett's T3 test $(P \leq 0.05)$ following one-way ANOVA of the IBM SPSS 22.0 software for Windows.

\section{Results}

\section{Effect of B. subtilis JN005 on Rice Seed Germination}

Significant growth promotion was observed in rice seeds treated with B. subtilis JN005 suspension (Fig. 1 and 
Table 1 Effect of Bacillus subtilis JN005 in suspension forms on rice seed germination

\begin{tabular}{lllll}
\hline Treatments & Germination energy (\%) & Germination rate $(\%)$ & Germination index & Vigor index \\
\hline Control & $81.00 \pm 0.58 \mathrm{c}$ & $82.33 \pm 1.45 \mathrm{c}$ & $145.93 \pm 0.45 \mathrm{c}$ & $10.22 \pm 0.03 \mathrm{c}$ \\
$1 \times 10^{6} \mathrm{cfu} / \mathrm{mL}$ & $87.67 \pm 0.67 \mathrm{~b}$ & $88.33 \pm 0.67 \mathrm{~b}$ & $158.68 \pm 1.50 \mathrm{ab}$ & $24.40 \pm 4.40 \mathrm{~b}$ \\
$1 \times 10^{7} \mathrm{cfu} / \mathrm{mL}$ & $93.67 \pm 0.67 \mathrm{a}$ & $94.00 \pm 1.00 \mathrm{a}$ & $167.11 \pm 2.82 \mathrm{a}$ & $37.81 \pm 2.57 \mathrm{a}$ \\
$1 \times 10^{8} \mathrm{cfu} / \mathrm{mL}$ & $89.33 \pm 0.67 \mathrm{~b}$ & $90.33 \pm 0.33 \mathrm{~b}$ & $163.04 \pm 1.33 \mathrm{ab}$ & $34.80 \pm 1.70 \mathrm{a}$ \\
\hline
\end{tabular}

Data were mean $\pm \operatorname{SE}(n=3)$, different lowercase letters within a column indicated significant difference at 0.05 level

\begin{tabular}{llllll}
\hline Treatments & Plant height $(\mathrm{cm})$ & Root length $(\mathrm{cm})$ & $\begin{array}{l}\text { Stem circum- } \\
\text { ference }(\mathrm{cm})\end{array}$ & $\begin{array}{l}\text { Aboveground } \\
\text { fresh weight }(\mathrm{g})\end{array}$ & $\begin{array}{l}\text { Underground } \\
\text { fresh weight }(\mathrm{g})\end{array}$ \\
\hline Control & $28.45 \pm 0.12 \mathrm{~d}$ & $2.88 \pm 0.02 \mathrm{c}$ & $2.59 \pm 0.06 \mathrm{c}$ & $8.51 \pm 0.10 \mathrm{~d}$ & $1.79 \pm 0.05 \mathrm{c}$ \\
$1 \times 10^{6} \mathrm{cfu} / \mathrm{mL}$ & $37.84 \pm 0.27 \mathrm{c}$ & $5.30 \pm 0.36 \mathrm{~b}$ & $3.50 \pm 0.02 \mathrm{~b}$ & $17.01 \pm 0.89 \mathrm{c}$ & $2.74 \pm 0.13 \mathrm{~b}$ \\
$1 \times 10^{7} \mathrm{cfu} / \mathrm{mL}$ & $41.67 \pm 0.02 \mathrm{a}$ & $6.54 \pm 0.01 \mathrm{a}$ & $4.00 \pm 0.10 \mathrm{a}$ & $19.59 \pm 0.47 \mathrm{a}$ & $3.40 \pm 0.13 \mathrm{a}$ \\
$1 \times 10^{8} \mathrm{cfu} / \mathrm{mL}$ & $40.27 \pm 0.16 \mathrm{~b}$ & $5.95 \pm 0.02 \mathrm{a}$ & $3.82 \pm 0.05 \mathrm{a}$ & $18.36 \pm 0.20 \mathrm{~b}$ & $2.99 \pm 0.00 \mathrm{~b}$ \\
\hline
\end{tabular}

Data were mean \pm SE $(n=3)$, different lowercase letters within a column indicated significant difference at 0.05 level
Table 2 Effect of Bacillus subtilis JN005 suspensions on the growth parameters of rice seedlings

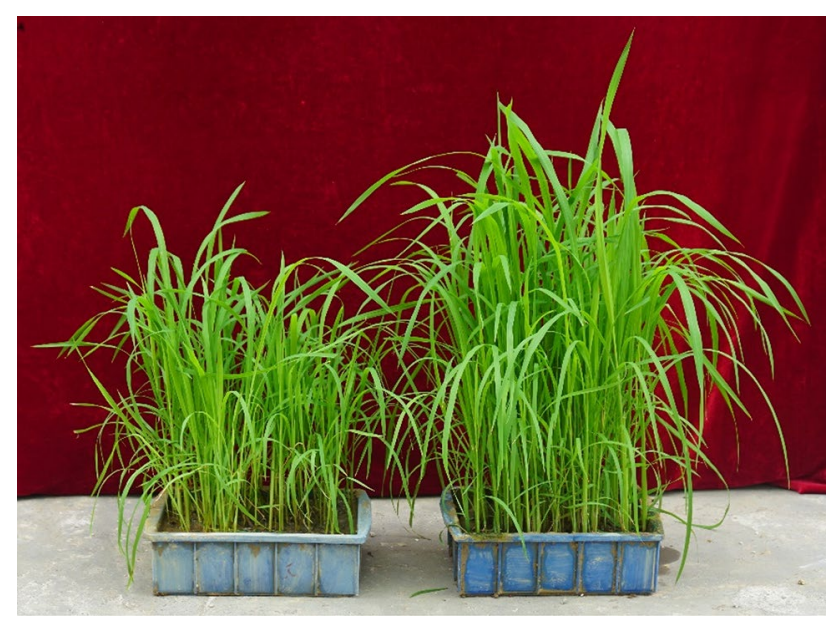

Fig. 2 Effect of Bacillus subtilis JN005 suspension at $1 \times 10^{7} \mathrm{cfu} / \mathrm{mL}$ treatment on rice seedlings (right) in comparison to the control or water treatment (left)

Table 1). Compared to the control or sterile water treatment (Table 1), rice seeds treated with B. subtilis JN005 suspension at a population density of $1 \times 10^{7} \mathrm{cfu} / \mathrm{mL}$ showed the highest germination energy at $(93.67 \pm 0.67) \%$, germination rate at $(94.00 \pm 1.00) \%$, germination index at $(167.11 \pm 2.82)$, and vigor index at $(37.81 \pm 2.57)$. Values obtained were $16 \%, 14 \%, 15 \%$, and $270 \%$ higher than values measured in germination energy, germination rate, germination index, and vigor index, respectively, from the control or sterile water treatment. Except on vigor index, the effects on rice seed germination from $1 \times 10^{6} \mathrm{cfu} / \mathrm{mL}$ bacterial cells treatments were not significantly different when compared with $1 \times 10^{8} \mathrm{cfu} / \mathrm{mL}$, but both treatments showed significantly higher values than the control treatment.

\section{Effect of B. subtilis JN005 on Rice Seedlings}

Growth parameters were measured with the application of $B$. subtilis JN005 suspension in potted rice seedlings, namely plant height, root length, stem circumference, and fresh weight (Table 2). Compared with water treatment, results show that $B$. subtilis JN005 suspension treatments exhibited growth-promoting effects on rice seedlings (Fig. 2). With the decrease of the concentration of B. subtilis JN005 suspension, the growth-promoting effect first increased and all
Table 3 Effect of Bacillus subtilis JN005 suspension on chlorophyll content of rice seedlings

\begin{tabular}{llll}
\hline Treatments & Chlorophyll a $(\mathrm{mg} / \mathrm{L})$ & Chlorophyll b $(\mathrm{mg} / \mathrm{L})$ & $\begin{array}{c}\text { Total chloro- } \\
\text { phyll }(\mathrm{mg} / \mathrm{L})\end{array}$ \\
\hline Control & $1.32 \pm 0.06 \mathrm{~d}$ & $0.53 \pm 0.03 \mathrm{~d}$ & $1.85 \pm 0.03 \mathrm{~d}$ \\
$1 \times 10^{6} \mathrm{cfu} / \mathrm{mL}$ & $1.98 \pm 0.02 \mathrm{c}$ & $0.67 \pm 0.02 \mathrm{c}$ & $2.65 \pm 0.04 \mathrm{c}$ \\
$1 \times 10^{7} \mathrm{cfu} / \mathrm{mL}$ & $3.45 \pm 0.09 \mathrm{a}$ & $1.35 \pm 0.02 \mathrm{a}$ & $4.80 \pm 0.07 \mathrm{a}$ \\
$1 \times 10^{8} \mathrm{cfu} / \mathrm{mL}$ & $2.17 \pm 0.01 \mathrm{~b}$ & $0.88 \pm 0.01 \mathrm{~b}$ & $3.05 \pm 0.03 \mathrm{~b}$ \\
\hline
\end{tabular}

Data were mean \pm SE $(n=3)$, different lowercase letters within a column indicated significant difference at 0.05 level 
the indexes reached the maximum and then decreased when the concentration reached $1 \times 10^{7} \mathrm{cfu} / \mathrm{mL}$. The B. subtilis JN005 suspension of $1 \times 10^{7} \mathrm{cfu} / \mathrm{mL}$ increased root plant height (46\%), root length (127\%), stem circumference (54\%), aboveground fresh weight (130\%), and underground fresh weight (90\%) as compared to the control after 35 days. The B. subtilis JN005 inoculation induced changes in chlorophyll concentration. When rice seedlings leaves were inoculated with three concentrations of $B$. subtilis JN005, the chlorophyll concentration became elevated compared to those uninoculated ones. Maximum significant improvement was observed in $1 \times 10^{7} \mathrm{cfu} / \mathrm{mL}$ bacterial cells inoculated leaves

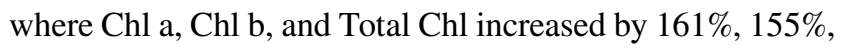
and $159 \%$, respectively, compared to the sterile water or control treatment (Table 3).

\section{Effect of B. subtilis JN005 on Defense Enzymes Activity}

In theory, B. subtilis JN005 induces the CAT, PAL, POD, and SOD activities in rice leaves. Results show that activities of CAT, PAL, and SOD increased gradually, peaking at three days after application of B. subtilis JN005 suspension of $1 \times 10^{7} \mathrm{cfu} / \mathrm{mL}$ (Fig. 3A, B, and C). Figure $3 \mathrm{D}$ shows that the activities of POD in the rice leaves increased dramatically after treatment with $B$. subtilis JN005 suspension, and activity was highest at $1 \times 10^{7} \mathrm{cfu} /$ $\mathrm{mL}$ bacterial cells on the fifth day. The POD activity showed longer duration, while other enzymes activities were opposite. The activities of CAT, PAL, SOD, and POD significantly increased in the plants treated with the combination suspensions of $B$. subtilis JN005 and M. oryzae spores (T4) compared to pathogen-inoculated positive control (T2). Rice leaves treated with the B. subtilis JN005 suspension alone (T3) also showed significantly higher enzymatic activity compared to the water treatment (T1) and the pathogen-inoculated treatment (T2).

\section{Effect of B. subtilis JN005 on Rice Blast Development on Detached Rice Leaves}

B. subtilis JN005 suspensions were tested for its ability to control $M$. oryzae through in vitro inoculation on rice leaves. Typical blast disease spots on rice leaves were observed (Fig. 4), and disease incidence was $100.00 \%$ in both the preventive and the curative groups inoculated with
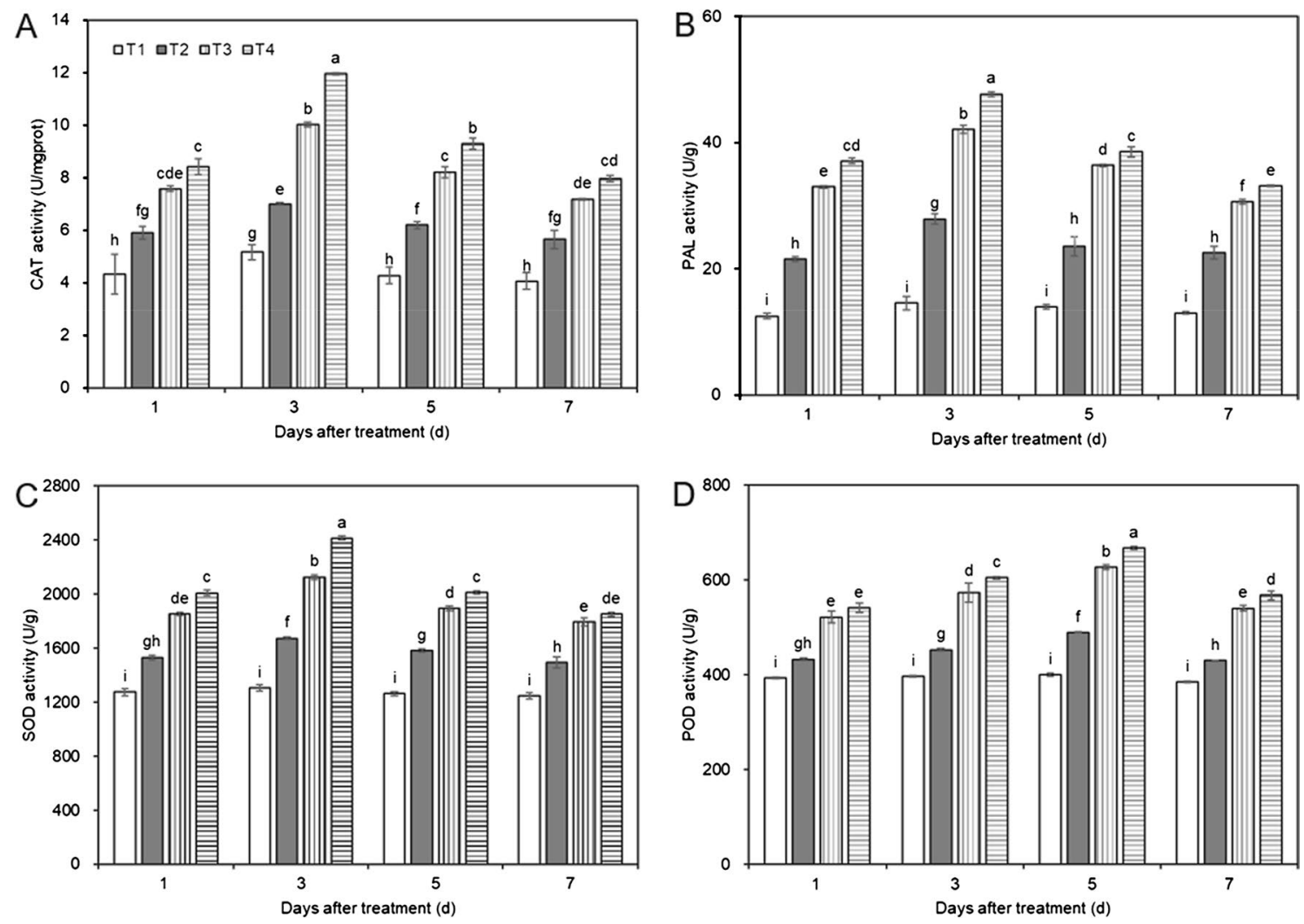

Fig. 3 Effect of Bacillus subtilis JN005 on the activities of defense enzymes: A catalase (CAT), B phenylalanine ammonialyase (PAL), C superoxide dismutase (SOD), and D peroxidase (POD). T1 Water,

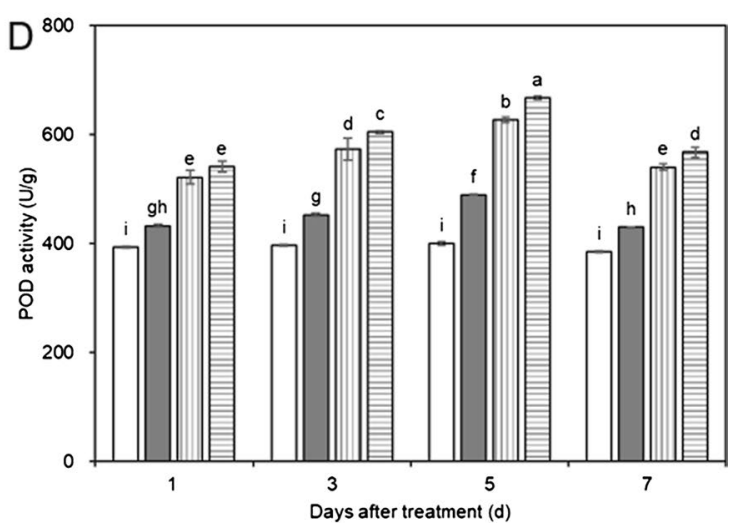

T2 $2 \times 10^{5}$ conidia/mL M. oryzae suspension, T3 $1 \times 10^{7} \mathrm{cfu} / \mathrm{mL} B$. subtilis JN005 suspension, T4 $1 \times 10^{7} \mathrm{cfu} / \mathrm{mL}$ B. subtilis JN005 suspension $+2 \times 10^{5}$ conidia/mL $M$. oryzae spore suspension 


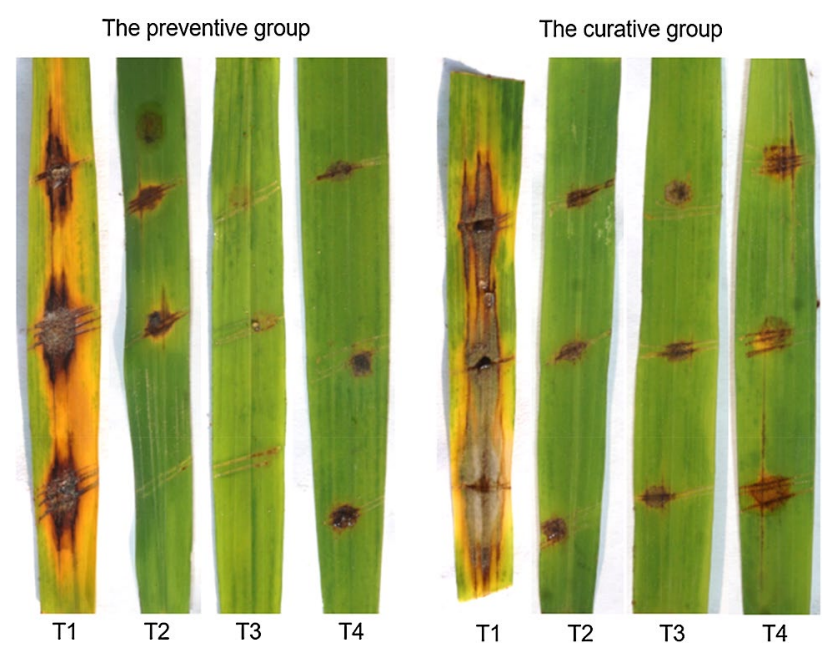

Fig. 4 Effect of Bacillus subtilis JN005 on rice blast development on detached rice leaves. T1 Sterile water, T2 $40 \%$ isoprothiolane EC, T3 $75 \%$ tricyclazole WP, T4 $1 \times 10^{7} \mathrm{cfu} / \mathrm{mL}$ B. subtilis JN005 suspension

sterile water as control. In treatments with $1 \times 10^{7} \mathrm{cfu} / \mathrm{mL}$ bacterial suspension, symptoms observed were significantly reduced, with disease incidence of only $(20.74 \pm 0.74) \%$ and $(24.44 \pm 1.28) \%$ in the preventive and in the curative groups, respectively. These results suggest that the JN005 strain displayed preventive effect and weak curative effect against the leaf blast. Additionally, the JN005 strain showed a comparable control effect of leaf blast with $40 \%$ isoprothiolane EC, but it was not as excellent as the $75 \%$ tricyclazole WP treatment (Table 4).

\section{Effect of B. subtilis JN005 on Rice Blast in the Field}

The biocontrol efficacy of $B$. subtilis JN005 was conducted in field trials as well and the results are shown in Table 5. Compared with fungicide, B. subtilis WP and B. subtilis JN005 suspension $\left(1 \times 10^{7} \mathrm{cfu} / \mathrm{mL}\right)$ showed similar levels of disease control. At seedling and maturity stages, rice treated with water (control) showed the most serious disease symptoms with disease indexes of $(3.66 \pm 0.21)$ and $(5.28 \pm 0.69)$, respectively. Meanwhile, rice treated with B. subtilis JN005 suspension $\left(1 \times 10^{7} \mathrm{cfu} / \mathrm{mL}\right)$ had disease indexes of $(1.58 \pm 0.13)$ and $(2.16 \pm 0.13)$ at seedling and maturity stages, respectively, which were comparable to indexes of $(1.32 \pm 0.32)$ and $(1.64 \pm 0.25)$ measured in rice treated with $B$. subtilis WP. After spraying $B$. subtilis JN005 $\left(1 \times 10^{7} \mathrm{cfu} / \mathrm{mL}\right)$, rice blast was controlled up to $(56.82 \pm 1.12) \%$ and $(58.39 \pm 3.05) \%$ at seedling and maturity stages, respectively. The spray application of $B$. subtilis JN005 and fungicide $B$. subtilis WP in rice resulted in the plants' overall vegetative growth improvement. Compared to the control, significant increases in rice yields were obtained from treatments of B. subtilis JN005 suspension $\left(1 \times 10^{7} \mathrm{cfu} /\right.$ $\mathrm{mL})$ at $54 \%$ and fungicide $B$. subtilis WP treatment at $43 \%$. The values are mean of data trials conducted in 2 years.

\section{Discussion}

The fungus $M$. oryzae is one of the most destructive plant pathogens. It can cause outbreak of rice blast disease that could pose threats to global food security. Bacillus spp. has
Table 4 In vitro inoculation of Bacillus subtilis JN005 on detached rice leaves to showcase leaf blast incidence

Table 5 Biocontrol effects of Bacillus subtilis JN005 and WP on field-grown rice plants in two-year trial

\begin{tabular}{llcc}
\hline Treatment & Dilution ratio & $\begin{array}{c}\text { The preventive group } \\
\text { Disease incidence }(\%)\end{array}$ & $\begin{array}{l}\text { The curative group } \\
\text { Disease incidence (\%) }\end{array}$ \\
\hline Control (sterile water) & 0 & $100.00 \pm 0.00 \mathrm{a}$ & $100.00 \pm 0.00 \mathrm{a}$ \\
$40 \%$ isoprothiolane EC & 500 & $25.18 \pm 0.74 \mathrm{~b}$ & $22.96 \pm 0.74 \mathrm{~b}$ \\
$75 \%$ tricyclazole WP & 1500 & $9.63 \pm 1.48 \mathrm{~d}$ & $13.33 \pm 1.28 \mathrm{c}$ \\
$1 \times 10^{7}$ cfu/mL B. subtilis JN005 & 0 & $20.74 \pm 0.74 \mathrm{c}$ & $24.44 \pm 1.28 \mathrm{~b}$ \\
\hline
\end{tabular}

Data were mean $\pm \operatorname{SE}(n=3)$, different lowercase letters within a column indicated significant difference at 0.05 level

\begin{tabular}{|c|c|c|c|c|c|}
\hline \multirow[t]{2}{*}{ Treatments } & \multicolumn{2}{|l|}{ Seedling } & \multicolumn{2}{|l|}{ Maturity } & \multirow[t]{2}{*}{ Rice yield $\left(\mathrm{g} / \mathrm{m}^{2}\right)$} \\
\hline & Disease index & Efficacy $(\%)$ & Disease index & Efficacy (\%) & \\
\hline Control & $3.66 \pm 0.21 \mathrm{a}$ & - & $5.28 \pm 0.69 a$ & - & $340.55 \pm 12.55 b$ \\
\hline $\begin{array}{l}\text { B. subtilis JN005, } \\
10^{7} \mathrm{cfu} / \mathrm{mL}\end{array}$ & $1.58 \pm 0.13 b$ & $56.82 \pm 1.12$ & $2.16 \pm 0.13 b$ & $58.39 \pm 3.05$ & $524.40 \pm 17.88 \mathrm{a}$ \\
\hline B. subtilis WP & $1.32 \pm 0.32 b$ & $65.45 \pm 7.18$ & $1.64 \pm 0.25 b$ & $62.74 \pm 7.13$ & $488.15 \pm 13.69 a$ \\
\hline
\end{tabular}

Data were mean $\pm \operatorname{SE}(n=6)$, different lowercase letters within a column indicated significant difference at 0.05 level 
a well-recognized potential against crop diseases and most of biocontrol agents have been developed from Bacillus spp. For example, B. subtilis GB03, known by its product name Companion, can antagonize Fusarium, Pythium, and Rhizoctonia (Dhakal and Singh 2019).

This research illustrated that the germination energy, germination rate, germination index, and vigor index of rice seeds treated with $B$. subtilis JN005 suspension $\left(1 \times 10^{7} \mathrm{cfu} /\right.$ $\mathrm{mL}$ ) have high values compared to measurements from sterile water or control treatment. Similarly, various growth parameters of rice seedlings were enhanced, such as plant height, root length, stem circumference, and fresh weight in rice seeds with all $B$. subtilis JN005 treatments compared to the control treatment. Leaves of rice seedlings inoculated with B. subtilis JN005 resulted in increased chlorophyll concentration than the water treatment. Therefore, results clearly indicate that germination and growth of rice seeds reinforce the role of Bacillus spp. as a plant growth promoter, as well as the findings of some previous studies (Naseer et al. 2020; Liu et al. 2020; Gholamalizadeh et al. 2017).

In fact, Bacillus spp. promote plant health and plant growth through nitrogen fixation, phosphate solubilization, and phytohormone production (Tiwari et al. 2019). Nitrogen-fixing microorganisms can absorb elemental nitrogen from the atmosphere and form compounds that serve as plant nutrients (Kuan et al. 2016). Phosphate solubilization microorganisms can help plant roots to accelerate the absorption of organic and inorganic phosphates from soil (Garcia and Delgado 2016). Bacillus spp. may directly raise plant yield via mechanisms that impart the production of phytohormones or plant growth regulators, such gibberellins, auxins, and ethylene (Park et al. 2017; Shahzad et al. 2017; Vicente et al. 2019). Additionally, this study revealed that rice yields of plants with B. subtilis JN005 treatments $(524.40 \pm 17.88) \mathrm{g} /$ $\mathrm{m}^{2}$ were higher than the water control $(340.55 \pm 12.55) \mathrm{g} /$ $\mathrm{m}^{2}$ and fungicide $B$. subtilis WP $(488.15 \pm 13.69) \mathrm{g} / \mathrm{m}^{2}$ treatments. Similarly, rice yields in treatments $B$. siamensis $624.10 \mathrm{~g} / \mathrm{m}^{2}$ were found significantly higher than the untreated control $484.10 \mathrm{~g} / \mathrm{m}^{2}$ (Thampiban et al. 2018).

One effective biological control for multiple pathogens is the activation of the defense systems in the host plant (Jamali et al. 2020). This study showed that the accumulations of CAT, PAL, SOD, and POD in rice leaves were higher in the B. subtilis JN005 treatments compared to both the pathogen challenged and sterile water or control treatments. The results suggest that $B$. subtilis JN005 helped reduce the oxidative damage caused by the pathogen, $M$. oryzae through the upregulation of CAT, PAL, SOD, and POD activities. The JN005 strain triggered the plant's defense mechanism that helped the plant to improve its resistance against pathogen infection. These findings are parallel with earlier reports implying the potential of biocontrol Bacillus spp. toward strengthening the defense enzymes activities that build up the defensive mechanism of rice plants against diseases (Rais et al. 2017; Elshakh et al. 2016).

Isoprothiolane and tricyclazole are extensively used fungicides on rice blast (Rijal and Devkota 2020; Elamawi et al. 2018). Inoculation experiment of detached rice leaves showed no significant difference between the JN005 strain $1 \times 10^{7} \mathrm{cfu} / \mathrm{mL}$ suspension and fungicide $40 \%$ isoprothiolane EC in controlling M. oryzae, but tricyclazole $75 \%$ WP was found to be most effective among three treatments. Additionally, B. subtilis JN005 had better preventive effect than its curative effect for leaf blast control. The results of a 2-year field experiment studies revealed lower blast disease indexes in the B. subtilis JN005-treated group at $(1.58 \pm 0.13)$ and $(2.16 \pm 0.13)$ during seedling and maturity stages of rice plants, respectively, compared with $(1.32 \pm 0.32)$ and $(1.64 \pm 0.25)$ derived from the $B$. subtilis WP-treated group. B. subtilis JN005 and B. subtilis WP have almost similar effects to blast disease; thus, the JN005 strain exhibits great promise in suppressing disease severity following $M$. oryzae infection. Consequently, the JN005 strain may be potentially used for the biocontrol of rice blast and its antagonistic activity indicates a prospect for practical applications in agriculture sustainable development.

Reportedly, Bacillus spp. excrete extracellular metabolites, such as antibiotics, cell wall hydrolases, and siderophores that have antagonistic activity on plant pathogens (Miljaković et al. 2020; Kaspar et al. 2019). For example, $B$. amyloliquefaciens strains VB7 reduced stem rot incidence in greenhouse-grown carnations and that antimicrobial compounds detected include fatty acids and phenols (Vinodkumar et al. 2017). Hence, a future study on B. subtilis JN005 will be conducted to determine which antibiotics it produces that curtail the incidence of plant diseases.

Acknowledgements This research was supported by the National Key Research and Development Program of China (2016YFD0300700), the central government-financed projects, China (2014ZX0800102B), and the public welfare industry (agriculture) special scientific research projects, China (201203014). We thank LetPub (www.letpub.com) for its linguistic assistance during the preparation of this manuscript.

Author Contributions All authors contributed substantially.

\section{Declarations}

Conflict of interest All of the authors declare that they do not have any conflict of interest.

Open Access This article is licensed under a Creative Commons Attribution 4.0 International License, which permits use, sharing, adaptation, distribution and reproduction in any medium or format, as long as you give appropriate credit to the original author(s) and the source, provide a link to the Creative Commons licence, and indicate if changes were made. The images or other third party material in this article are included in the article's Creative Commons licence, unless indicated otherwise in a credit line to the material. If material is not included in 
the article's Creative Commons licence and your intended use is not permitted by statutory regulation or exceeds the permitted use, you will need to obtain permission directly from the copyright holder. To view a copy of this licence, visit http://creativecommons.org/licenses/by/4.0/.

\section{References}

Ahmad Z, Wu J, Chen L, Dong W (2017) Isolated Bacillus subtilis strain 330-2 and it's antagonistic gen-es identified by the removing PCR. Sci Rep 7(1):1-13. https://doi.org/10.1038/ s41598-017-01940-9

Anhar A, Sari NP, Advinda L, Putri DH, Handayani D (2019) Effect of the indigenous Trichoderma application on germination of black glutinous rice seed. J Phys: Conf Ser 1317(1):012065. https://doi. org/10.1088/1742-6596/1317/1/012065

Asibi AE, Chai Q, Coulter JA (2019) Rice blast: a disease with implications for global food security. Agronomy 9(8):451. https://doi.org/ 10.3390/agronomy 9080451

Barratt BIP, Moran VC, Bigler F, Van Lenteren JC (2018) The status of biological control and recommendations for improving uptake for the future. Biocontrol 63:155-167. https://doi.org/10.1007/ s10526-017-9831-y

Bisht N, Mishra SK, Chauhan PS (2020) Bacillus amyloliquefaciens inoculation alters physiology of rice (Oryza sativa L. var. IR-36) through modulating carbohydrate metabolism to mitigate stress induced by nutrient starvation. Int J Biol Macromol 143:937-951. https://doi.org/10.1016/j.ijbiomac.2019.09.154

Chen Z, Zhao L, Chen W, Dong Y, Yang C, Li C, Xu H, Gao X, Chen $\mathrm{R}, \mathrm{Li} \mathrm{L}, \mathrm{Xu} Z$ (2020) Isolation and evaluation of Bacillus velezensis ZW-10 as a potential biological control agent against Magnapo-rthe oryzae. Biotechnol Biotechnol Equip 34(1):714-724. https://doi.org/10.1080/13102818.2020.1803766

Dhakal R, Singh DN (2019) Biopesticides: a key to sustainable agriculture. Int J Pure Appl Biosci 7(3):391-396. https://doi.org/10. 18782/2320-7051.7034

Elamawi RM, Mostafa FA, El-Shafey RAS (2018) Monitoring of tricyclazole and isoprothiolane residues and their effects on blast disease, yield and its components, grain quality and chemical components of rice. J Plant Prot Pathol 9(9):557-566. https://doi. org/10.21608/JPPP.2018.43760

Elshakh AS, Anjum SI, Qiu W, Almoneafy AA, Li W, Yang Z, Cui ZQ, Li B, Sun GC, Xie GL (2016) Controlling and defence-related mechanisms of Bacillus strains against bacterial leaf blight of rice. J Phytopathol 164(7-8):534-546. https://doi.org/10.1111/ jph.12479

Emoghene AO, Futughe AE (2016) Fungi as an alternative to agrochemicals to control plant diseases. Fungal applications in sustainable environmental biotechnology. Springer, Cham, pp 43-62. https://doi.org/10.1007/978-3-319-42852-9_3

Garcia-Lopez AM, Delgado A (2016) Effect of Bacillus subtilis on phosphorus uptake by cucumber as affected by iron oxides and the solubility of the phosphorus source. Agric Food Sci 25(3):216224. https://doi.org/10.23986/afsci.56862

Gholamalizadeh R, Khodakaramian G, Ebadi AA (2017) Assessment of rice associated bacterial ability to enhance rice seed germination and rice growth promotion. Braz Arch Biol Technol. https:// doi.org/10.1590/1678-4324-2017160410

Hashem A, Tabassum B, Abd Allah EF (2019) Bacillus subtilis: a plant-growth promoting rhizobacteriau-m that also impacts biotic stress. Saudi J Biol Sci 26(6):1291-1297. https://doi.org/10. 1016/j.sjbs.2019.05.004

He Y, Zhu M, Huang J, Hsiang T, Zheng L (2019) Biocontrol potential of a Bacillus subtilis strain BJ-1 against the rice blast fungus
Magnaporthe oryzae. Can J Plant Path 41(1):47-59. https://doi. org/10.1080/07060661.2018.1564792

Jamali H, Sharma A, Srivastava AK (2020) Biocontrol potential of Bacillus subtilis RH5 against sheath blight of rice caused by Rhizoctonia solani. J Basic Microbiol 60(3):268-280. https://doi. org/10.1002/jobm.201900347

Jangir M, Pathak R, Sharma S, Sharma S (2018) Biocontrol mechanisms of Bacillus sp., isolated from to-mato rhizosphere, against Fusarium oxysporum f. sp. lycopersici. Biol Control 123:60-70. https://doi.org/10.1016/j.biocontrol.2018.04.018

Kaspar F, Neubauer P, Gimpel M (2019) Bioactive secondary metabolites from Bacillus subtilis: a compre-hensive review. J Nat Prod 82(7):2038-2053. https://doi.org/10.1021/acs.jnatprod.9b00110

Kuan KB, Othman R, Abdul Rahim K, Shamsuddin ZH (2016) Plant growth-promoting rhizobacteria in-oculation to enhance vegetative growth, nitrogen fixation and nitrogen remobilisation of maize under greenhouse conditions. PLoS ONE 11(3):e0152478. https:// doi.org/10.1371/journal.pone.0152478

Lastochkina O, Pusenkova L, Yuldashev R, Babaev M, Garipova S, Blagova DY, Khairul-lin R, Aliniaeifard S (2017) Effects of Bacillus subtilis on some physiological and biochemical parameters of Triticu-m aestivum L. (wheat) under salinity. Plant Physiol Biochem 121:80-88. https://doi.org/10.1016/j.plaphy.2017.10.020

Liu Z, Wang H, Xu W, Wang Z (2020) Isolation and evaluation of the plant growth promoting rhizobact-erium Bacillus methylotrophicus (DD-1) for growth enhancement of rice seedling. Arch Microbiol. https://doi.org/10.1007/s00203-020-01934-8

Majeed A (2018) Application of agrochemicals in agriculture: benefits, risks and responsibility of stakehol-ders. J Food Sci Toxicol 2(1): 3. http://www.imedpub.com/journal-food-science-toxicology/. Accessed 5 Dec 2020

Miah G, Rafii M Y, Ismail M R, Sahebi M, Hashemi F S G, Yusuff $\mathrm{O}$, Usman M G (2017) Blast disea-se intimidation towards rice cultivation: a review of pathogen and strategies to control. J Anim Plant Sci 27: 1058-1066. http://www.thejaps.org.pk/ docs/v-27-04/01.pdf. Accessed 5 Dec 2020

Miljaković D, Marinković J, Balešević-Tubić S (2020) The significance of Bacillus spp. in disease suppression and growth promotion of field and vegetable crops. Microorganisms 8(7):1037. https://doi.org/10.3390/microorganisms8071037

Naseer I, Ahmad M, Hussain A, Jamil M (2020) Potential of zinc solubilizing Bacillus strains to improve rice growth under axenic conditions. Pak J Agric Sci. https://doi.org/10.21162/ PAKJAS/20.9988

Park YG, Mun BG, Kang SM, Hussain A, Shahzad R, Seo CW, Kim AY, Lee SU, Oh KY, Lee DY, Lee IJ, Yun BW (2017) Bacillus aryabhattai SRB02 tolerates oxidative and nitrosative stres-s and promotes the growth of soybean by modulating the production of phytohormones. PLoS ONE 12(3):e0173203. https://doi. org/10.1371/journal.pone.0173203

Rais A, Jabeen Z, Shair F, Hafeez FY, Hassan MN (2017) Bacillus spp., a bio-control agent enhances the activity of antioxidant defense enzymes in rice against Pyricularia oryzae. PLoS One 12(11):e0187412. https://doi.org/10.1371/journal.pone.0187412

Rijal S, Devkota Y (2020) A review on various management method of rice blast disease. Malays J Sustain Agric 4(1):14-18. https:// doi.org/10.26480/mjsa.01.2020.29.33

Shahzad R, Khan AL, Bilal S, Waqas M, Kang SM, Lee IJ (2017) Inoculation of abscisic acid-produc-ing endophytic bacteria enhances salinity stress tolerance in Oryza sativa. Environ Exp Bot 136:68-77. https://doi.org/10.1016/j.envexpbot.2017.01. 010

Sowanpreecha R, Kanchanabanca C, Sangvanich P, Rerngsamran P (2018) Bacillus subtilis N3 as a Biocontrol agent for Curvularia lunata and its antifungal protein properties. Int J Agric Biol 20(3):531-538. https://doi.org/10.17957/JJAB/15.0511 
Sun D, Zhuo T, Hu X, Fan X, Zou H (2017) Identification of a Pseudomonas putida as biocontrol agent for tomato bacterial wilt disease. Biol Control 114:45-50. https://doi.org/10.1016/j.bioco ntrol.2017.07.015

Tan T, Zhu J, Shen A, Li J, Yu Y, Zhang M, Zhao M, Li Z, Chen J, Gao C, Cheng Y, Guo L, Yan L, Sun X, Zeng L, Yan Z (2019) Isolation and identification of a Bacillus subtilis HZ-72 exhibiting biocontrol activity against flax seedling blight. Eur J Plant Pathol 153(3):825-836. https://doi.org/10.1007/s10658-018-1595-4

Thampiban-udom P, Charoenrak P, Intanoo W, Chamswarng C (2018) Efficacy of Bacillus siamensis strain in managing sheath blight, enhancing grain yields and decomposing rice stubble and straw. J Int Soc Southeast Asian Agric Sci 24(2):116-128. http://issaa sphil.org/wp-content/uploads/2019/01/11.-Thampiban-udom-etal-2018-Bacteria-Rhizoctonia-Rice-FINAL.pdf. Accessed 2 Dec 2020

Tiwari S, Prasad V, Lata C (2019) Bacillus: Plant growth promoting bacteria for sustainable agriculture and environment. New Future Dev Microb Biotechnol Bioeng. https://doi.org/10.1016/B978-0444-64191-5.00003-1

Vicente-Hernández A, Salgado-Garciglia R, Valencia-Cantero E, Ramírez-Ordorica A, Hernández-García A, García-Juárez P, Macías-Rodríguez L (2019) Bacillus methylotrophicus M4-96 stimulates the growth of strawberry (Fragaria $\times$ ananassa 'Aromas') plants in vitro and slows botrytis cinerea Infection by two different methods of interaction. J Plant Growth Regul 38(3):765777. https://doi.org/10.1007/s00344-018-9888-6
Vinodkumar S, Nakkeeran S, Renukadevi P, Malathi VG (2017) Biocontrol potentials of antimicrobial peptide producing Bacillus species: multifaceted antagonists for the management of stem rot of carnation caused by Sclerotinia sclerotiorum. Front Microbiol 8:446. https://doi.org/10.3389/fmicb.2017.00446

Wang M, Cernava T (2020) Overhauling the assessment of agrochemical-driven interferences with microbial communities for improved global ecosystem integrity. Environ Sci Ecotechnol 4:100061. https://doi.org/10.1016/j.ese.2020.100061

Xu JX, Li ZY, Lv X, Yan H, Zhou GY, Cao LX, Yang Q, He YH (2020) Isolation and characterization of Bacillus subtilis strain 1-L-29, an endophytic bacteria from Camellia oleifera with antimicrobial activity and efficient plant-root colonization. PLOS ONE 15(4):e0232096. https://doi.org/10.1371/journal.pone.0232096

Zhang P, Zhu Y, Ma D, Xu W, Zhou J, Yan H, Yang L, Yin J (2019) Screening, identification, and optimization of fermentation conditions of an antagonistic endophyte to wheat head blight. Agronomy 9(9):476. https://doi.org/10.3390/agronomy9090476

Zhu J, Tan T, Shen A, Yang X, Yu Y, Gao C, Li Z, Cheng Y, Chen J, Guo L, Sun X, Yan Z, Li J, Zeng L (2020) Biocontrol potential of Bacillus subtilis IBFCBF-4 against Fusarium wilt of watermelon. J Plant Pathol 102:433-441. https://doi.org/10.1007/ s42161-019-00457-6

Publisher's Note Springer Nature remains neutral with regard to jurisdictional claims in published maps and institutional affiliations. 